\title{
General and Relative Growth Studies in Formulated Feed of Fresh Water Prawn M. Assamensis peninsularis (Tiwari) from Kumaon Himalaya, Uttarakhand
}

\author{
MAMTA JOSHI ${ }^{\star}$, NANDKISHOR A. INGOLE ${ }^{1 *}$, H.C.S. BISHT and N.N. PANDEY ${ }^{1}$ \\ Department of Zoology, D.S.B. Campus, Kumaon Univerity, Nainital, Uttrakhand, India. \\ ${ }^{1}$ ICAR-DCFR, Bhimtal, Nainital-263136, Uttrakhand, India. \\ ${ }^{\star}$ Corresponding author E-mail: amitisha2006@yahoo.com \\ http://dx.doi.org/10.12944/CWE.11.3.27
}

(Received: August 25, 2016; Accepted: November 29, 2016)

\begin{abstract}
The present paper deals with the study of relative growth of fresh water prawn Macrobrachium assamensis peninsularis. Experiment was conducted to study the effect of different formulated diets. The experiment diets were prepared with similar ingredient composition with only difference in protein supplement source. The stocked animals were fed with control diet $\left(D_{0}\right)$ and three experimental diets $\left(D_{1}-D_{3}\right)$. The food was given at 8 am and $4 \mathrm{pm}$ at the rate of $5 \%$ of the total biomass. Study was conducted during July 2007- June 2008. The relative per month growth increment was observed maximum in the case of animal fed with diet $D_{3}$ followed by animal fed with diet $D_{2}$. It was $2.08 \mathrm{~mm}$ in male and 1.44 in female for per month increment in length of animal fed with diet $D_{3}$ and $0.11 \mathrm{gm}$ in males and $0.073 \mathrm{gm}$ in females for per month increment in weight of the same group of animals. Finally concluded that formulated feed to enhanced the relative growth of both the sexes under laboratory condition.
\end{abstract}

Keyword: Relative growth, Formulated feed and Freshwater Prawn.

\section{INTRODUCTION}

The present status of fresh water prawn production has been the interest of research and commercial enterprise in United States. The primary production techniques were well developed in the late 1950s in Malasiya, Israil and Hawai in last four decades ${ }^{1}$. In India (1985) the prawn culture is developed as an industry, and many experimental programs were developed to make the prawn culture as a alternative to fish culture.

At this time prawn culture is completely developed as industry that is very beneficial to the farmers and prawn culturist. The fresh water prawn culture is probably the only accepted diversified farming practice being taken up in commercial scale in the country, which is largely driven by higher market value of the produce in the international market. The giant fresh water prawn, Macrobrachium rosenbergii has been the principal species, adopted both under monoculture and mixed farming of fresh water prawn with carps, Andhra Pradesh has been the lead producer with contribution of $86.6 \%$ of the total fresh water producing of about 43,000 tons in the country at present.

The commercially economic food is necessary for an organism. The production cycle requires the good quality food, stocking method pre stocking preparation and managing water quality parameters ${ }^{2}$. The feeding frequency should be balanced, excess feeding or over feeding not only reduce potential revenue but also earn lead to poor water quality that can impair growth of prawns ${ }^{3}$. Success of freshwater prawn farming depends greatly on the availability of good quality seeds and nutritionally balanced feed with low Food Conversion 
Ratio (F.C.R) which appears superior growth performance within the stipulated period. Freshwater prawns are formed in many parts of the tropical world. Unlike Penaeid shrimps, freshwater prawns are grown on low protein and relatively inexpensive dies ${ }^{4}$.

Some of these small prawns are economically important and demand in the market. Their species include Macrobrachium assamensis peninsularis (Tiwari), M. hendersosdaynum and M. lammarrii. The characterstic features, easy availability in nature almost throughout the year, high hatching rate and recent success achieved mass rearing under controlled conditions. The freshwater Palaemonid prawn of the cold climate M. assamensis peninsularis currently offers a good potential for large scale commercial aquaculture primarily because established techniques are available for larval rearing, the animal breeds under captivity, attain a very good growth rate within 4 or 5 months in culture condition and show good survival rate. Under natural condition, $M$. assamensis peninsularis is an omnivore feeding on various plant and animal material ${ }^{5}$. Though this species accepts a wide variety of food in captivity, it particularly prefers flesh of mollusca and crustaceans ${ }^{6-7}$. Though extensive works have been undertaken on the use of pelleted feeds ${ }^{7-8}$ to enhance production of freshwater prawns under culture conditions, the use of quality formulated feeds for growing stock of $M$. assamensis peninsularis is yet to be accomplished.

The freshwater prawn of the present interest $M$. assamensis peninsularis belonging to the category of minor prawn found in many rivers of Kumaon region of Uttarakhand. This species is size-wise and availability wiz it is fairly comparable with the other exploitable species of minor prawns in our country and plays an important role in protein rich local food resources. There is no biological data on this prawn exists in literature till date, except a few morphological characteristics in one of survey notes. It was therefore, of interest to observations on certain lines of the food and feeding habitats of $M$. assamensis peninsularis in systematic pattern to collect the basic details required for obtaining a rational prawn fishery of the key challenges in the mountainous region of Uttarakhand is to improve the access to natural resources and the findings are embodied in this paper. Commercially, the use of ingredients in formulated feed should be costeffective and should be available in large quantities in areas where culture operations are to be carried out. Further prepared formulated feed should have high water stability. In the present study, three types of formulated feeds with different ingredients having almost similar protein levels and a control feed were used to assess the growth of freshwater prawn, $M$. assamensis peninsularis under experimental conditions.

\section{MATERIAL AND METHOD}

The present studies were carried out on the prawn, Macrobrachium assamensis pennisularis (Tiwari) (Crustacea, Decapoda, Palaemonidae) inhabiting in the stream Ganyapani at Chaukhutia district Almora in the Kumaon Himalaya of Uttarakhand. The prawns were carefully transported to laboratory in suitable plastic contains about 40 liter capacity and were allow to minimum 96 hours acclimatization before being used in experimental study. During acclimatization prawns were maintained in aquaria with continuous aeration and were fed on natural food like algae and zooplankton. The method adopted in investigation of various biological aspects is based on standard evolved in different research laboratories both in India and abroad. Whenever necessary, the methodology was modified to suit the local conditions.

Juveniles of Macrobrachium assamensis pennisularis were collected from tributaries of Ramganga river (West) at Chaukhutia (alt.1150 m asl, 34 $50^{\prime} 6^{\prime} \mathrm{N}$ Lat. and $27^{\circ} 23^{\prime} 13^{\prime \prime} \mathrm{E}$ long.) district Almora in the Kumaon Himalaya of Uttarakhand during the month of July 2007- June 2008. Collection was done using a scoop net of the meshed cloth (mesh size; $1 \mathrm{~mm}^{2}$ ). Collected juveniles were transported live under oxygen packing to the experimental site, DCFR, Bhimtal. The prawns were acclimatized for 2 weeks, in the FRP troughs and were separated in different FRP troughs (Size: $300 \times 60 \times 30 \mathrm{~cm}$.) as per designed accordingly. 50 juveniles were stocked in each trough. The prawns were acclimatized for 2 weeks, in the FRP troughs and were separated in different FRP troughs (Size: $300 \times 60 \times 30 \mathrm{~cm}$.) as per designed accordingly. 50 juveniles were stocked in each trough. 100 specimens were kept separately for 
the Gastro-somatic Index (GSI) and Feeding Index (FI) study.

Initial mean weight and average length of Juveniles were recorded at the time of stocking. Study was conducted during July 2007 to June 2008. The stocked animals were fed with control diet $\left(D_{0}\right)$ and three experimental diet $\left(D_{1}-D_{3}\right)$ having same levels of dietary protein with different ingredients composition. First trough was fed with conventional diet, while second was fed with Soybean incorporated diet, third was fed with fish meal incorporated diet and last trough was fed with Soybean and fish meal incorporated diet. The ingredient composition of each diet was analyzed. These diets were prepared with similar ingredients composition with only difference in protein supplement source i.e.-soybean and fish meal. The ingredients used in the feed were accurately weighted and the feed were prepared following method described by ${ }^{9}$. Bio-chemical analyzed was also made for different feeds proximate composition of each diet was estimated by adopting standard procedures ${ }^{10}$. The formulated feeds were prepared with almost same levels of specific protein sources. Feed was prepared as steam pelleted diet $(2.4 \mathrm{~mm})$ and crushed in small granule suit the mouth size of the animal. Each diet was analyzed for crude protein, crude fat, Ash content and moisture content. Crude protein analysed by micro Kjeldahal method, crude fat was analyzed by ether extract estimation and moisture and ash content were also analyzed. Sample of oven-dried prawns were analyzed for crude protein, crude fat, moisture and ash content as per method adopted for proximate composition of feed.

The growth rate of fish was measured in terms of gain in length and weight. Sampling was done at monthly intervals by netting out 10 prawns of each experiment and length and weight of each specimen measured separately. Observations for disease or infection were also made for each group. The length was measured to the nearest $\mathrm{mm}$ from the eye orbit to the tip of telson. Weight was recorded after removing the excess water using tissue paper on absorbent. The increase in length and weight were used as measures of growth.

The monthly growth increment in this species was calculated by adopting the Peterson's method. Relative growth rate relationships between carapace length $(C L)$, abdominal length- $A B L$ and total length (TL) were established on the basis of measurements taking for these parts. Following equation was applied for further analysis-

$$
\mathrm{Y}=\mathrm{b} X^{@}
$$

Where $X=$ reference organ of known size from which the size of the other organ $Y$ will be determined. B and @ are constants. Being nonproductive in terms of meat, rostrum and telson parts were not considered.

The length weight relationship of the experimental prawn is worked out as per cube law given by ${ }^{14}$ as follows:

$$
W=C L^{3}
$$

$\mathrm{W}=$ weight of fish

$\mathrm{C}=$ Constant factor

$L=$ Length of fish

The logarithmic transformation of the above formula is

$$
\text { Low } W=\log a+n \log L
$$

The length-weight data was further utilized to calculate the relative condition factor $(\mathrm{Kn})$. The $\mathrm{Kn}$ values were calculated separately in both the sexes for all the months of the year to examine seasonal fluctuations. GSI, FI, PER is also calculate to study the prawn growth indices.

The water samples were collected in sampling bottles from each trough at 10-11 AM for the estimation of $\mathrm{pH}$, dissolved oxygen, free carbon dioxide, alkalinity Dissolved oxygen was measured at experimental site itself while rest of the parameters were analyzed in the laboratory. Water temperature was also measured at experimental site.

\section{RESULT AND DISCUSSION}

Asia accounts for over $80 \%$ of the world's fish production ${ }^{11}$. In the light of conflicting demand for land and water, fish culture practices need to be intensified to varying degrees, mostly through increasing levels of supplemental feeding. For 
any sustainable culture practices the quality food and their feeding frequency play an important role. A variety of feed ingredients of both plant and animal origin are used in preparing artificial diet in intensive culture, the quantity and quality of protein in the diet were seen to influence fish growth. In fishes much of the protein is converted into flesh during the growth. Protein is expensive and hence becoming a dearer commodity for biotic organisms. The dietary proteins requirements for a particular species or a group of species are different. But, ${ }^{12}$ observed that specific differences in optimal protein requirement within a group are varying narrow. Much work has been done on the nutritional requirements of various fish species but studies on the role of microbial community especially of fermented feeds are scanty ${ }^{13-14}$. However, studies have shown quite significant impact of microbial communities on the growth of fish ${ }^{15-18}$.

The basic objective of the study embodies the evaluation of role of formulated diets on growth performance and development in the juveniles of Macrobrachium assamensis peninsularis. The whole experiment was conducted in one year (July, 2007 June, 2008). Applying normal diet $\left(D_{0}\right)$ to the growing prawn juveniles in the control unit (trough - 1) and test diet $\left(D_{1}-D_{3}\right)$ to the experimental units (trough: $2-4)$. Diet $D_{0}$ was prepared with conventional feed ingredients, which were fed to animals of controlled group. Diet $D_{1}$ was prepared with soybean meal and other common ingredients without any animal source of protein. Diet $D_{2}$ was prepared with fishmeal while diet $D_{3}$ was prepared with soybean meal and

Table 1: Gastosomatic Index (GSI) and Feeding Index (FI) Macrobranchium assamensis peninsularis feed with diet $D_{0}$

\begin{tabular}{|c|c|c|c|c|}
\hline \multirow[t]{2}{*}{ Months } & \multicolumn{2}{|c|}{ Gastro-Somatic Index (GSI) } & \multicolumn{2}{|c|}{ Feeding Index (FI) } \\
\hline & Male & Female & Male & Female \\
\hline July 2007 & $1.73 \pm 0.15$ & $2.66 \pm 0.81$ & $35.65 \pm 5.62$ & $34.47 \pm 7.31$ \\
\hline Aug 2007 & $1.63 \pm 0.14$ & $2.12 \pm 0.63$ & $26.35 \pm 3.08$ & $35.32 \pm 8.64$ \\
\hline Sep 2007 & $1.74 \pm 0.16$ & $2.14 \pm 0.64$ & $25.46 \pm 5.41$ & $29.56 \pm 6.34$ \\
\hline Oct 2007 & $1.47 \pm 0.35$ & $1.61 \pm 0.52$ & $27.23 \pm 6.30$ & $26.07 \pm 8.39$ \\
\hline Nov 2007 & $1.52 \pm 0.28$ & $1.83 \pm 0.22$ & $27.15 \pm 3.73$ & $27.18 \pm 3.85$ \\
\hline Dec 2007 & $1.15 \pm 0.07$ & $1.20 \pm 0.07$ & $23.48 \pm 4.43$ & $25.34 \pm 5.13$ \\
\hline Jan 2008 & $1.05 \pm 0.02$ & $1.42 \pm 0.23$ & $24.69 \pm 6.04$ & $26.32 \pm 6.24$ \\
\hline Feb 2008 & $2.07 \pm 0.43$ & $1.67 \pm 0.16$ & $37.16 \pm 4.61$ & $36.35 \pm 6.04$ \\
\hline Mar 2008 & $2.26 \pm 0.67$ & $2.13 \pm 0.05$ & $36.43 \pm 6.02$ & $34.36 \pm 4.26$ \\
\hline Apr 2008 & $2.64 \pm 0.18$ & $2.62 \pm 0.53$ & $32.07 \pm 4.26$ & $35.06 \pm 8.19$ \\
\hline May 2008 & $2.47 \pm 0.37$ & $3.12 \pm 0.64$ & $37.57 \pm 7.25$ & $37.63 \pm 5.83$ \\
\hline June 2008 & $2.91 \pm 0.81$ & $2.54 \pm 0.26$ & $38.16 \pm 9.32$ & $35.16 \pm 4.47$ \\
\hline
\end{tabular}

Table 2: Food Conversion Ratios (FCR)

\begin{tabular}{lcccccccccc}
\hline Diet No. & \multicolumn{2}{c}{$\begin{array}{c}\text { Initial } \\
\text { Biomass } \mathbf{( g m})\end{array}$} & $\begin{array}{c}\text { Total food } \\
\text { intake } \mathbf{( g m )}\end{array}$ & $\begin{array}{c}\text { Final } \\
\text { Biomass(gm) }\end{array}$ & \multicolumn{2}{c}{$\begin{array}{c}\text { Yield } \\
\text { (gm) }\end{array}$} & F.C.R \\
\hline D0 & Male & Female & Male & Female & Male & Female & Male & Female & Male & Female \\
Control & 0.34 & 0.39 & 3.40 & 2.79 & 1.48 & 0.90 & 1.14 & 0.51 & 2.98 & 3.10 \\
D1 Soybean meal & 0.36 & 0.38 & 2.83 & 1.54 & 1.58 & 1.01 & 1.18 & 0.63 & 2.40 & 2.45 \\
D2 Fish meal & 0.35 & 0.39 & 2.69 & 1.70 & 1.62 & 1.18 & 1.27 & 0.79 & 2.12 & 2.16 \\
D3 Soybean and & 0.34 & 0.38 & 2.77 & 1.83 & 1.68 & 1.26 & 1.38 & 0.88 & 2.01 & 2.08 \\
Fish meal & & & & & & & & & &
\end{tabular}


fishmeal both. Soybean meal and fishmeal both is very commonly used protein supplement ingredient in the aquaculture diet. Presently, the whole world aquaculture industry is in the grip of fishmeal for protein supplementation. The present test prawn species is a coldwater organism and required high protein level in the supplementary diet. Being an expensive ingredient, fishmeal increases the cost of supplementary feed in aquaculture practice. Hence, a combination of soybean and fishmeal was also tested in the supplementary diet of test animal.

There is a significant contribution of crustaceans in inland aquaculture production. The prawn species Macrobrachium assamensis peninsularis would be a candidate species for coldwater aquaculture practice after development of complete culture package of this species. The feeding behavior of prawns has been shown to undergo variation with season ${ }^{19}$. However, no work had been done in prawns to study feeding intensities and their seasonal fluctuations on their seasonal fluctuation on the basis of Gastro-somatic and feeding indices.

The prawns juvenile are very delicate and their culture should must be conduct under indirect sunlight with an intensity ranging from 30,000 to 7,00000 lux, a level typical of a partly cloudy to a clear day. The artificial light should never be used as an exclusive substitute for natural light. The experiment was conducted in re-circulating systems at a water temperature of 8.0 to $26.5^{\circ} \mathrm{C}$.

The use of re-circulation systems allow for efficient use of water. Stream water was used for the experiment and passed through an 8-micron bag filter before entering in to raceways run off from stream was examined to many of the pesticides because the prawns are very sensitive for them. Also avoid use of streams that are subject to drift from agricultural sprays or to run-off water potentially contaminated with pesticides. A water sample was also screened for pesticide contamination. The raceways were rectangular shape to facilitate

Table 3: Regression equations of length-weight relationship and ' $r$ ' values in different tested groups

\begin{tabular}{lll}
\hline Test diet & Equation determined & “ $r$ " Value \\
\hline Control $\left(D_{0}\right)$ & $\mathrm{w}=0.000011692 \mathrm{~L}^{2.9899 \text { (Male) }}$ & 0.70353 \\
& $\mathrm{~W}=0.000080316 \mathrm{~L}^{2.4432 \text { (Female) }}$ & 0.48054 \\
Experimental $\left(\mathrm{D}_{1}\right) \quad$ (Soybean meal $)$ & $\mathrm{W}=0.00004692 \mathrm{~L}^{2.9574 \text { (Male) }}$ & 0.60251 \\
& $\mathrm{~W}=0.000148836 \mathrm{~L}^{2.3077 \text { (Female) }}$ & 0.58731 \\
Experimental $\left(\mathrm{D}_{2}\right)($ Fish meal $)$ & $\mathrm{W}=0.000052406 \mathrm{~L}^{2.7541 \text { (Male) }}$ & 0.87432 \\
& $\mathrm{~W}=0.000029115 \mathrm{~L}^{2.7782 \text { (Female) }}$ & 0.82211 \\
Experimental $\left(\mathrm{D}_{3}\right)$ (Soybean and Fish meal) & $\mathrm{W}=0.000053601 \mathrm{~L}^{2.6271 \text { (Male) }}$ & 0.92543 \\
& $\mathrm{~W}=0.000057832 \mathrm{~L}^{2.6210 \text { (Female) }}$ & 0.90299 \\
\hline
\end{tabular}

Table 4: Relative growth increment with different test diets during July, 2007 to June, 2008

\begin{tabular}{|c|c|c|c|c|}
\hline \multirow[t]{2}{*}{ Test diet } & \multicolumn{2}{|c|}{$\begin{array}{l}\text { Average length } \\
\text { per month (mm) }\end{array}$} & \multicolumn{2}{|c|}{$\begin{array}{l}\text { Average weight } \\
\text { per month (gm) }\end{array}$} \\
\hline & Male & Female & Male & Female \\
\hline Control $\left(D_{0}\right)$ & 1.67 & 1.28 & 0.095 & 0.040 \\
\hline Soybean meal $\left(D_{1}\right)$ & 1.85 & 1.38 & 0.098 & 0.050 \\
\hline Fish meal $\left(D_{2}\right)$ & 2.06 & 1.40 & 0.100 & 0.065 \\
\hline Soybean and Fish meal $\left(D_{3}\right)$ & 2.08 & 1.44 & 0.111 & 0.073 \\
\hline
\end{tabular}


distribution of feed across the entire surface area of water. The raceways provided some soil bricks for shelter of prawns.

The important life processes such as the general and relative growths and attainment of sexual maturity are important parameters in the biology of candidate species of aquaculture, particularly prawns ${ }^{20-21}$. The knowledge of the growth rate may also be useful in assessing the holding capacity of rearing ponds as well as the potential of productivity of a particular fishery stock. In prawn, flesh meat is mainly limited to the abdominal part. Growth in these creature results into certain size alterations between various parts of the body ${ }^{22}$ and therefore, the study of relation between the growth of abdomen and other parts including total length of the prawn may provide useful information regarding the ideal size for fishing ${ }^{23}$. Macrobrachium assamensis peninsularis is a minor prawn species found abundantly in the mountainous region of Kumaon Himalayas and has a great potential for being a candidate species for coldwater aquaculture practice ${ }^{24}$. The present study is an attempt to reveal the general and relative growth rates of Macrobrachium assamensis peninsularis based on formulated diet of desired nutritional requirement. All four-test diets contain similar ingredients with only difference in the protein supplement ingredient having almost similar protein level in the range of 35.12 to $52.68 \%$. Proteins are indispensable nutrients for all living organisms including prawns. Nutrition studies of prawn often start with investigating the optimal dietary protein level. As a consequence, the most researched nutrient is protein ${ }^{24}$. The estimate of protein requirement must be carefully examined because it is dependent on the quality (essential amino acid profile) of dietary protein, age or physiological state of crustaceans and environment ${ }^{24}$. Studies have shown that prawns require the ten essential amino acids, namely, arginine, methionine, valine, threonine, isoleucine, leucine, lysine, histidine, phenylalanine and tryptophan. However, it has also been demonstrated that juveniles and adults are incapable of efficiently utilizing free amino acids or hydrolyzed protein products in the diet and diets containing only amino acids instead of protein brought about very poor growth and high mortality in feeding trials ${ }^{25-26}$. The test group of prawn fed with diet $D_{3}$ having soybean meal and fishmeal as protein source showed best growth. This may be due to better profile of amino acids and efficient use of dietary protein. The incorporation of soybean meal with fishmeal improves the amino acid profile as well as lower the feed cost. In the present investigation it has been reflected that soybean meal and fishmeal combination is a better protein supplement ingredient in the diet of coldwater prawn. It has been also experience that the required dietary protein level of this species is in the range of $40-50 \%$.

It was also observed that the average crude protein level in the prawn carcass was $23.07 \%$. While crude fat and Ash content was relatively lower, $0.23 \%$ and $0.41 \%$ respectively. Previous investigator also reported higher protein level in prawn carcass as $21.17 \%, 20.50 \%$ and $20.90 \%$ in fresh water prawn, mud prawn, Indian white prawn respectively with lower content of fat and ash. The higher protein content in the prawn carcass also reflects the higher protein requirement in the prawn diet.

The Gastro-Somatic Index (GSI) and Feeding Index (FI) are useful indicators to study the rate of feeding in an animal. However, no information is available on the rate of feeding in prawns based on these indices. ${ }^{33}$ have correlated the feeding intensity variations of fish with the availability of food material as well as the state of sexual cycle.

The present monthly variations in the GSI and $\mathrm{FI}$, which more or less follow the similar trend, exhibit a definite seasonal alteration in the gross feeding intensity of Macrobrachium assamensis peninsularis. The period of higher GSI and FI values is also in concurrence with the period when the fullness of gastric mill was found maximum.

In present study the values of GastroSomatic Index (GIS) measure each month for both the sexes of $M$. assamensis peninsularis are in the range of 1.20 to 3.12 . Females showed relatively higher values of GSI in comparison to males during entire study period. Relatively low growth of female is probably related to the supply of extra energy needed for active gonadal maturation. Almost parallel to the trend of fluctuations observed in GSI, the values of the feeding indices $(\mathrm{FI})$ also remained high in both the sexes of the concerned prawn. It was observed in the range of $23.48 \pm 4.43-38.16 \pm 9.32$ in case 
of male and $25.34 \pm 5.13-37.63 \pm 5.83$ in case of females. (Table 1)

As for the food conversion efficiencies, obtained a food conversion ratio (FCR) of 17.0: 1 for Macrobrachium lamarrei with trash fish. ${ }^{10}$ evaluated the same ratio as $10.0: 1$ for $M$. lanchesteri with Tubifex worms.

According to ${ }^{34}$ an arbitrary FCR of $2: 1$ may be required for tropical prawns before the economic viability of their culture can be considered. The present FCRs of 2.01 and 2.08 with soybean and fish meal incorporated diet, 2.40 and 2.45 with soybean meal incorporated diet, 2.12 and 2.16 with fish meal incorporated diet and 2.98 and 3.10 with conventional diet reflects the omnivorous feeding habit with better utilization of vegetable as well as animal source of protein in male prawn. In female prawn, the FCR shows slightly higher than males but better than the other species. Better protein efficiency rate in case of $D_{3}$ diet fed animals also support the efficiency of protein in supplementary feed by both the sexes of prawns. (Table 2).

While studying the length weight relationship in $M$. assamensis peninsularis, the following equation has been used to establish the relationship ${ }^{35}$.

$$
W=\varnothing L \theta
$$

Where,

$\mathrm{W}=$ Total weight; (gm)

$\mathrm{L}=$ Total length; $(\mathrm{cm})$

$\varnothing=\mathrm{e}^{\mathrm{a}}$

$\theta=b$

The validity of using the above-mentioned equation, in which the plotting of the log transformed empirical points of the two concerned parameters, shows their relationship to be linear. On the other hand, it was reflected when the data on total length and total weight was plotted without their transformation into log values, the relationship came out to be parabolic (Table 3 ).

The regression equations calculated in the present study show that there is a strong relationship between the lengths and weights of both the sexes of M. assamensis peninsularis $(r=0.99$ at $P<0.01)$. The relationship, however, exhibits a sexual dimorphism in this prawn because the equations obtained for male and female individuals are quite different. The value of the exponent's è in the equations calculated for the whole year was 2.6271 for males and 2.6210 for females and it shows that the males, in general, are slightly heavier than females. In conformity with the present observations, the length-weight relationship has been shown to be different in the males and females of M. malcolmsonii ${ }^{35-37}$.

In $M$. assamensis peninsularis, monthly fluctuations in the values of relative condition factor have been observed in both the sexes but they do not show any relationship with the sexual cycle of this species. Fluctuating conditions factor $(\mathrm{Kn})$ without any definite cycle in relation to reproduction has been observed among fishes ${ }^{38}$.

At the time of stocking the average initial weight of the female was relatively higher $(0.39 \pm$ $0.05 \mathrm{gm})$ than the male $(.34 \pm 0.02 \mathrm{gm})$. The average initial length was little higher in the case of males $(29.42 \pm 0.62 \mathrm{~mm})$ then the female $(28.54 \pm 0.43$ $\mathrm{mm})$. At the time of harvest the body weight of the males was observed significantly higher $(1.48 \pm$ $0.08 \mathrm{gm})$ than the females $(0.90 \pm 0.06 \mathrm{gm})$. Male also posses relatively higher body length $(48 \pm 0.58$ $\mathrm{mm}$ ) than the females $(42.62 \pm 1.32 \mathrm{~mm})$. In the both sexes maximum growth was gained by the group of animals fed with diet $D_{3}$ followed by the group of animals fed with diet $D_{2}$. Relatively per month growth increment was observed as maximum in the case of animals fed with diet $D_{3}$ followed by animals fed with diet $D_{2}$. It was $2.08 \mathrm{~mm}$ in males and $1.44 \mathrm{~mm}$ in females for per month increment in length of the animals fed with diet $D_{3}$ and $0.111 \mathrm{gm}$ in males and $0.073 \mathrm{gm}$ in females for per month increment in weight of the same group of animals (Table-4)

In $M$. assamensis peninsularis, monthly fluctuations in the values of relative condition factor have been observed in both the sexes but they do not show any relationship with the sexual cycle of this species. Fluctuating conditions factor $(\mathrm{Kn})$ without any definite cycle in relation to reproduction has been observed among fishes ${ }^{38}$. In present study, relatively higher survival rate, $80-88 \%$ indicates the better survival of prawn under culture operation. 
Water quality plays important role in growth and survival of aquatic organisms. It is determined by various physical, chemical and biological parameters of water body. The water quality is just an important in achieving maximum growth of fresh water prawn. Water temperature was found in the range of $8.0-26.5^{\circ} \mathrm{C}$, minimum during the month of January and maximum during the month of August - September. Seasonal fluctuation due to the climate change as well as light fluctuation in different troughs due to different water flow rate was observed during the course of study. In the present study, water temperature was found favorable for prawn growth. Dissolved Oxygen (DO) is the most crucial factor for the growth and survival of prawn in the raceways. Dissolved oxygen mainly evolves through the process of photosynthesis and flow of water. Dissolved oxygen remained in sub optimal level (5.4 - $10.4 \mathrm{mg} / \mathrm{l})$ with minimum level during the month of April and maximum during the month of November. In summer months, DO was low in all troughs due to increasing water temperature have concluded that the $\mathrm{pH}$ of the raw water sources mostly lies within the range 6.5 - 8.5. According to ${ }^{39}$, better fish production could be possible in pond water with $\mathrm{pH}$ value ranging 6.5 - 9.0. In present study, the $\mathrm{pH}$ values were recorded in the range of $6.6-8.2$ during the study period, which indicates the favorable condition for prawn growth. Gradual decrease in $\mathrm{pH}$ value during monsoon season supports the report of 40-41. Presence of $\mathrm{CO}_{2}$ is essential for photosynthesis but its excess is harmful to aquatic organisms. The free carbon dioxide contributes to the fitness of water as it serves to buffer the environment against rapid shifts in the acidity or alkalinity and also regulates biological processes in aquatic communities and can form many compounds.

Free $\mathrm{CO}_{2}$ appeared in moderate concentration in all the troughs during almost entire period of study. The values were relatively lower during summer and post monsoon months. ${ }^{42}$ also registered the same pattern of carbon dioxide distribution in fishponds.

Alkalinity in the water is its capacity to neutralize acid and is characterized by the presence of hydroxyl ions capable of combining with hydrogen ions in solution. Alkalinity, therefore, is a measure of buffering capacity of the water. The range of total alkalinity in the cold water may be found from 40 ppm to $100 \mathrm{ppm}$. Total alkalinity range in experimental troughs 74 to $98 \mathrm{ppm} .{ }^{43}$ suggested the range between 100-120 ppm for optimal fish production. Comparatively low values of alkalinity in experiment troughs indicate better conducive condition for growth with high $\mathrm{pH}$ and low free $\mathrm{CO}_{2}$. There was a relationship among the carbon dioxide, alkalinity and $\mathrm{pH}$.

\section{CONCLUSION}

Water quality plays important role in growth and survival of freshwater prawn. Strong relationship between the lengths and weights has to both the sexes in M. assamensis peninsularis. Females higher values of $\mathrm{GSI}$ in comparison to males.

\section{REFERENCES}

1. D. Abramo, L.R., W.H. Daniels, M.W. Fondren and M.W. Brunson. 1995. Management practices for culture of freshwater shrimp (Macrobrachium rosenbergii) in temperate climates. Bulletin 1030. Mississippi Agricultural Forestry Experimental Station, Mississippi State University, Starkville, Mississippi.

2. Dasgupta, S. 2005. Economics of freshwater prawn farming in the United States. Southern Regional Aquaculture Centre (SRAC). Publication No. 4830.

3. Louis, R. Abramo, D. James H., Tidwell.,
Marck Fondren and Cortney L. Ohs. 2006. Pond production of the freshwater prawn in temperate climates. Southern Regional Aquaculture Centre (SRAC). Publication No. 484. July.

4. Mitra, G., Chattopadhyay, D.N. and Mukhopadhyay, P.K., 2005. Nutrition and feeding in freshwater prawn (Macrobrachium rosenbergii) farming. Aqua. Feeds: Formulation and beyond 2 (1) : 17 - 19

5. Balazs, G.H., Ross, E. 1978. Effect of protein source and level on growth performance of 
the captive freshwater prawn, $M$. rosenbergii. Aquaculture, 7: 299 - 313.

6. Deshimaru, O. and Shigueno, K. 1972 Introduction to the artificial diet for prawn $P$. japonicus. Aquaculture, 1 : 115 - 133.

7. Forster, J.R.M. 1976. Studies on the development of compounded diets for prawns. In: S.P. Kent, W.N. Shaw and K.S. Danberg (Editors), Proc. of the First International Conference on Aquaculture Nutrition. Lewes / Rohaboth, Delaware, Coll. Mar. Stud., Univ. Delaware, Newark. 229 - 248.

8. Balazs, G.H., Ross, E., Brooks C.C. and Fujimura T. 1974. Effect of protein source and level on growth performance of the captive freshwater prawn, M. rosenbergii. Proceedings world Mariculture society, 5 : 1 - 14.

9. Louis, R. Abramo, D. and Shinsheen 1994. Nutritional reuirements, feed formulation and feeding practices for intensive culture of the freshwater prawn M. rosenbergii Reviews in Fisheries Science, 2 (1) : 1 - 21.

10. Jeyaram, M.G. and Shetty H.P.C. 1981. Formulation, processing and water stability of two new pelleted fish feeds. Aquaculture, 23 : 355 - 359.

11. De Silva, S.S. and Davy, F.B. 1992. Fish nutrition research for semi-intensive culture systems in Asia. Asian Fish Sci., 5 : 129 144.

12. Oser, B.L., 1971. Hawk's Physiological Chemistry $14^{\text {th }}$ Ed. Tata Mcgraw - Hill Publishing Co. Ltd. 1210.

13. Simpson, G.C., Roe, A. and Lewontin, R.C. 1960. Quantitative Zoology Harcourt, Brace and Company, New York, 440.

14. Le Cren, E. D. 1951. The length -weight relationship and seasonal cycle in gonadal weight and condition in the perch (Perca flaviatilis). J. Anim. Ecol. 20 : $201-219$.

15. De Silva, S.S. and Gunasekera, R.M. 1989. Effect of dietary protein level and amount of plant ingredients (Phaseolus aureus) incorporated into the diets on consumption, growth performance and carcass composition in Oreochromis niloticus (L.) Aquaculture. 80 : 121 - 133.

16. Shrinivasan, V.R. 1987. Conservation of cellulosic and other organic wastes into microbial proteins. ICLARM Canf. Proc. Manila. 181.

17. Malik, S. 1992. Microbial population and zooplankton production potentialities of selected organic and chemical fertilizers. M.Sc. thesis, RAU, Bikaner, India. 131.

18. Kumar, A. 1994. Evaluation of fishmin in relation to microbial and zooplankton population and fish growth. M.Sc. Thesis, RAU, Bikaner, India. 99.

19. Sharma, O. P. and Kumar, A. 1998. Growth of fingerlings of Cirrhinus mrigala (Ham.) in waters fertilized with fish-min. Fishing Chimes, 18 (5) : 15 - 16.

20. Santos, E.P. 1978. dinamica de populacoes aplicada a pesca e-piscicultura. Sao Paulo, HUCITEC / EDUSP. 130.

21. Kumar, A and Sharma, O. P. 1999. Fishmin : Its impact on the microbial and zooplankton production under agroclimatic condition of southern Rajsthan J. Aqua. Trop, 14 (1) : 75 - 84.

22. Kuttyamma, V.J.1974. Observation of the food of some Penaeid prawns of Cochin area. J. Mar. Biol. Ass. India. 15 : 189 - 194.

23. Gyananath, G. and Sarojini, R. 1986. Annual reproductive cycle of the prawn Macrobrachium lamerrii. Proc. Ist nat. Sysmp. Comp. Endocr. Invert. 56 - 60.

24. Valenti, W. C., Mello De, J.T.C., Lobao, V.L. 1987. Crescimento de Macrobrachium acanthurus (Wiegmann, 1836) do Rio ribeira de Iguape (Crustacea, Decapoda, Palaemonidae). Riv. Brasil. Biol. 47 : 349 355.

25. Valenti, W. C., Mello De, J.T.C., Lobao, V. L. 1989. Fecundidate em Macrobrachium acanthurus (Wiegmann, 1836) do Rio ribeira de Iguape (Crustacea, Decapoda, Palaemonidae). Ciencia e culture, 38 : 1256 - 1262.

26. Bisht, H.C.S., Kumar, S. and Joshi, N. 2002. General and relative growth studies on the common cold water prawn, $M$. assamensis peninsularis (Tiwari) from kumaon himalaya Him. J. Env. Zool. 16 (1) : 103 - 112.

27. Kumar. S., Bisht, H.C.S. and Kaur, J. 2000. In: Coldwater aquaculture and fisheries (Eds) H.R. Singh Allahabad and W.S. Lakra, Bombay. 
28. Venkataramiah, A., Lakshmi, G.I. and Gunter, G. 1975. Effect of protein level and vegetable matter on growth and food conservation efficiency of brown shrimp. Aquaculture 6 115 - 125.

29. Teshima, S., Kanazawa, A. 1984. Effect of protein, lipid and carbohydrate levels in purified diets on growth and survival rates of the prawn larvae. Bull. Ipn. Soc. Sci. Fish. $50: 1709-1715$.

30. Shiau, S.Y., Kwok, C.C., Chou, B.S. 1991a. Optimal dietary protein level of Penaeus monodon reared in seawater and brackish water. Nippon Suisan Gakkaishi 57 : 711 716.

31. D. Abramo, L.R., J.M. Heinen., H.R. Robinette and J.S. Collins. 1989. Production of the freshwater prawn Macrobrachium rosenbergii stocked as juveniles at different densities in temperature zone ponds. Journal of the World Aquaculture Society $20: 81$ - 89.

32. Deshimaru, O., Kuroki, K. 1974c. Studies on a purified diet for prawn: III. A feeding experiment with amino acid test diets. Bull. Jpn. Soc. Sci. Fish. 40 : 1127 - 1131.

33. Deshimaru, O., Kuroki. 1975a. Studies on a purified diet for prawn: IV. Evaluation of protein, free amino acids and their mixture as nitrogen source. Bull. Jpn. Soc. Fish. 41 : 101 - 103.

34. Kanazawa, A., Teshima, S.I. 1981. Essential amino acids of the prawn. Bull. Jpn. Soc. Sci. Fish. 47: 1357 - 77.

35. Hynes, H.B.N. (1950). The food of freshwater Sticlebacks (Gasterosteu aculeatus and Pygostens pungititius) with a review of methods used in studies of the food of fishes. J.Anim.Ecol., 19 : 36 - 58.
36. Ibrahim, K.H. 1962. Observation on the fishery and biology of the fresh water prawn Macrobrachium malcolmsonii (Milne Edwards) of river godavari. Ind. J. Fish, New Delhi. 9: 433 - 467.

37. Bond, G. and Buckup, L. 1983. O cultivo de Macrobrachium borellii (Nobli 1986) e de Macrobrachium potiuna (Miller, 1980) em Laboratorio (Crustacea, Decapoda, Palaemonidae), Rev. Bras. Biol., Rio de Janeiro. 43 : 177 - 190.

38. Valenti, W. C. 1984. Estudo populacional dos camaroe de aqua doce Macrobrachium acanthurus(Wiegmann, 1836) Macrobrachium carcinus (Linnaeus, 1758), do Rio de Iguape (Crustacea, Palaemonidae). Tese de Mestrado. Depot. De Biologia do Instituto de Biociencias da U.S.P. 149.

39. Narasimham, K.A. 1970. On the length -weight relationship and condition in Trichiurus lapturus Linnaeus. Ind. J. Fish. 17: 90 - 96.

40. Alabaster, J. S. and R. Lloyd. 1980. Water quality criteria for freshwater fish. FAO publication, p. 297.40. Webber, W.J. Jr. and Stumm 1963. Mechanism of hydrogen ion buffering in natural waters. J. Amer. Wet. Works Assoc. 155 : 1553

41. Sharma, O.P. and Saini, V.P. 1992. Evaluation of pig manure fertilization in relation to zooplankton production and water quality. $J$. Eco. Bial. 4(1) : 27 - 31.

42. Boyd CE, Pillai VK(1984). Water quality management in aquaculture. CMFRI, Spl. Pub. 22:1-96

43. Tripathi, C.K.M. 1982. Investigation on Ganga river to determine biological indicators of water quality. Ph.D. thesis, Banaras Hindu University, Varanasi. 193 - 211. 